\title{
The End of the Cold War and the Rise of New U.S.-Japan Relation
}

\author{
Kazuo Yagami \\ Coordinator of History Program \\ Savannah State University \\ Department of Social Behavioral Science
}

\section{Impact of the End of the Cold War}

While the trade friction between the United States and Japan was intensified, even reaching the point of prediction of war in the early 1990s, the world was witnessing an epoch-making event - the collapse of the Soviet Union in 1991. It ended roughly a half-century long Cold War that had shaped the world stage in politics, military, and economy in the post-WWII era. Naturally, this end to the Cold War made it inevitable for the world to go through some fundamental altercations economically and politically, including the United States-Japan relationship.

From the end of the war in 1945 to the conclusion of peace and security treaties in 1952 and subsequent treaty revision in 1960, the Cold War played a vital role in shaping the nature of the U.S.-Japan post-war relationship. Japan was put under the United States' protection economically, making the U.S. the most vital nation for Japan's economic recovery and growth. It had continued until the rise of Japan along with West Germany in the early1970s as a serious economic competitor against the United States. Militarily, the same thing can be said. There was, however, one contrast economy-wise. That is reciprocity regarding mutual benefits, "Give and Take." While the United States was vital for Japan militarily,Japan was perhaps to an even greater extent imperative militarily for the U.S. during the Cold War.Japan was fortunate to be able to rely on the U.S. military for national defense under the U.S.-Japan Security Treaty in 1952, which became one of the greatest contributors for Japan's speedy economic recovery and growth. The United States, under the same treaty, was formerly given a right to station its troops in various and strategically significant areas of Japan, most notably Okinawa, which became vital not just for defense of Japan but also for the U.S. to defend democracy and capitalism in Asia from the rising tide of communism led by the Soviet Union and increasingly China as well. This U.S. right to station its troops on the land of Japan, in a sense, became a cornerstone for the United States in the Cold War conflict. After losing Eastern Europe as a result of WWII, China to communism in 1949, and North Korea in 1953 due to the U.S. failure in the unification of Korea, any further U.S. setback in Asia could be fatal in its ideological confrontation against the Soviet Union. It would be tantamount to the U.S. defeat. Lastly, during the Cold War setting, not only economically and militarily, the U.S.-Japan relationship also determined Japan's position politically in the international arena. Japan, as a vanquished nation, had no choice but to follow the U.S. stance politically regarding the world affairs even to the extent that the other world powers labeled Japan only as a U.S. dependency.

\section{Sudden Downfall of the Japanese Economy}

No longer taken for granted assources of stability, these fundamental aspects of the U.S.-Japan relationship in the postPacific War, forged by the Cold War mentality and reality, naturally began to crumble as the Cold War was coming closer to an end as exemplified most prominently by the drastic turnaround of the Japanese economy in $1991 .{ }^{\mathrm{i}}$ The Japanese economy was seemingly unstoppable throughout the 1980s and reached the pinnacle of its success in the late 1980s, making the prediction of Ezor Vogal's "Japan as No. 1" ostensibly a reality. It was during this period that James Fallows wrote one of the most sensational and controversial articles, "Containing Japan," in 1989, arguing that Japan's economic expansion based on the sharply contrasting form of capitalism from that of the Western counterparts, if not stopped, might destroy the world's free economy. Equally sensational and controversial was the book, The Coming War with Japan by George Friedman and Meredith LeBard, as it made a bold prediction that, with Japan's robust and relentless economic expansion and simultaneously ailed U.S. economy, the war between the United States and Japan would be imminent and inevitable.

All these controversies, however, became non-issues when Japan's hearty economy took a sharp and sudden turnaround in 1991 from its heyday to haplessness. The anti-Japan Western economists wasted no time pointing out the nature of the "unsubstantiated" Japanese economic system, only relying on the Cold War creation, "the circumstantial benefits," and "unfair" trade practices for Japan's economic growth and its sustainability as the causes of this drastic reversal of the Japanese economy. 
They argued that, taking advantage of the Cold War conflict, Japan enjoyed a "free ride" in its economic development as can be seen in Japan's reliance on the U.S. military for its national defense that enabled Japan to have the United States' full devotion of resources and capital to economic recovery and growth and also U.S. procurements of war goods from Japan as the U.S. became heavily involved in the Korean War in the early 1950s and the Vietnam War in the 1960s and 1970s.

As this argument of the Western economists suggests, the Japanese economic "miracle" indeed seems to have been heavily based on "circumstantial" benefits, not anything fundamentally substantial; so what happened to the Japanese economy in 1991 was thelogical outcome of the end of the Cold War as it took away the circumstantial benefits from Japan.

From the intensified contentions between the Japan-bashers and Japan's admirers over the trade disputes between the United States and Japan in the 1980s, the above argument was expected at the moment of the sudden turnaround and sharp decline of the Japanese economy. While one might find it convincing, it was, however, nothing more than the Post-Cold War version of "Japan-bashing," and had little substance to it.

As the Western economists point out, it is true that Japan took advantage of the U.S. military shield for its national security needs and the U.S. procurement of war goods from Japan for its economic development. They are unarguably bolstering factors for the success of the Japanese economy, particularly in the initial stage of Japan's recovery from the war destruction. It is, however, surely "nonsensical" to argue that Japan's nearly half-century-long economic success in the post-WWII era - as one of the largest economies in the world with its technological advancement and being widely recognized as equal to that of the U.S. - still remains as one of the most advanced nations with its status as No. 3 in the economy even more than two decades after the end of the Cold War in 1991 are merely based on those circumstantial benefits alone.

No one can deny that Japan was "fortunate" to have those benefits during its economic development phase. The Japanese economic success had been well buttressed by not only the circumstantial benefits but far more greatly by Japan's cultural and social foundations such as its unshakably strong national identity, well planned economic development led by both the government and private sectors and highly advanced education system. Those are the same backbones for Japan's initial success in its economy and overall modernization shortly after Japan was obliged to end its seclusion by the United States in the mid- $19^{\text {th }}$ century.

So, a question has to be asked. If the end of Japan's free ride is not the prime cause of the sudden turnaround of the Japanese economy in early 1990s, then what brought it about? Here, although it is speculative, one can make a tangible and more credible argument as an answer to the question by examining why the end of the Cold War and Japan's sudden decline in its economy took place in the same year, 1991, almost simultaneously. While it was not the circumstantial benefits but the solid foundations of the Japanese society that played the most pivotal role in Japan's recovery and substantial growth in its economy in the post-WWII era, here is the "perception," however, no one can negate that it was this "free ride"-whether decisive or not - that made it greatly possible for Japan to have such success. The Cold War ended in 1991. With it so did that perception, replaced by an expectation that the United States, having no longer any validation for providing its defense shield for Japan, would terminate the security treaty with Japan. Therefore, Japan had no other choice but to defend itself by establishing its self-defense militarily, thus ending Japan's "free ride" and consequentially undermining the Japanese economy.Similarly, there is one other interesting argument regarding the "perception" generated by the end of the Cold War. Pertinent to the economic competition between the United States and Japan, there was one discerning advantage that Japan enjoyed throughout the post-WWII era economically. That is, while Japan was fully able to concentrate itself on economic development thanks to the U.S. providing a defense shield, the United States had no such blessing economically. The Cold War left no other choice for the U.S. but to pursue the containment of the rsing tide of communism led by the Soviet Union as its top priority, leaving the economy as a secondary issue. So, in a sense, throughout the Cold War era, the United States was competing with Japan economically with "one hand tied behind its back." Now, the United States found itself free from the burden of winning the war against communism, creating a perception and expectation that no longer politics but the economy would be the their top priority and so the U.S. would do better economically and out-compete Japan. ${ }^{\text {ii }}$

As one may find, the above arguments are convincing regarding why the end of the Cold War and the sudden decline of the Japanese economy - as seen particularly in the sharp drop in the Japanese stock market (losing approximately twothirds of its stock in a very short period) - that took place in 1991 while the U.S. market simultaneously showed substantial improvement. It was a valid argument to say, with the stock market highly susceptible to any change or fluctuation in economic and social conditions, the Japanese stock market indeed negatively and rather inescapably responded to those perceptional changes caused by the end of the Cold War while the U.S. market was going in the opposite direction. 
Thus, it is difficult to dispute the negative impact of such perceptional changes in the Japanese economy as a result of the end of the Cold War. There is, however, one other contributor, more direct and more convincing, for the sudden turnaround of the Japanese economy and subsequent prolonged economic stagnation of Japan. Surprisingly, this is something that has been the least discussed by the economic experts.

That is the rise of the other Asian nations as economic competitors against Japan, most notably that of the "Four Asian Tigers" (Hong Kong, Taiwan, South Korea, and Singapore) followed by China. These nations began to rise economically in the 1980s under the leadership of great figures such as Prime Minister of Singapore, Lee Kuan-yew, who came up with the well-known slogan for economic development, "Look East," suggesting learning from the economic success of Japan. His suggestion was well received. These nations made impressive rises as economic powerhouses by following the Japanese way of economic development throughout the 1980s. By the early 1990s, they began to position themselves as no longer "apprentices" of Japan but competitors.

Before the rise of these Asian neighbors as economic powers, Japan as a sole industrialized nation in Asia monopolized not only the Asian market but the world market as well as an Asian nation. In the early 1990s, however, instead of being the markets themselves for Japanese goods in Asia, these newly rising economic powers with highly advanced technology almost equal to that of Japan began to chip away Japan's long-lasting dominance in the Asian market as well as the world market as seen most prominently in the U.S. market. A great example of this can be seen in the field of electronics. During the pinnacle of Japan's economic success in the 1980s, Japanese corporations such as Matsushita and Sony with their high-quality goods and competitive prices were absolutely dominant in the U.S. market by outcompeting the U.S. domestic corporations and all other foreign competitors. That began to change, however, in the early 1990s when the non-Japanese corporations from Asia penetrated into the U.S. market. For example, today it is not Sony but South Korean company, Samsung, that enjoys the status Sony used to hold as a No. 1 world producer of electronic goods. The same thing can be said about the other fields, most notably that of automobiles. While facing competition from European automakers in the United States, Japan had never faced any competition from other Asian nations throughout the Cold War era. Today, it is no longer so. Japan faces stiff competition from South Korean automakers such as Hyundai and Kia. Seeing great rapidity in the rise of these Korean automakers as formidable competitors in the U.S. market, it is possible that, within a decade or so, what happened to Sony might happen to Toyota as a world top automaker, being replaced by Hyundai or Kia. So undeniably Japan's long-lasting status as a sole industrialized nation in Asia and its consequential dominance of the Asian market and the world market, particularly that of the U.S., began to fade in the early 1990s, explaining the sharp and rather sudden decline and prolonged stagnation of the Japanese economy more than anything else.

Here, it is interesting to note that this decline of Japan's economic competitiveness in the post-Cold War era due to the rise of other Asian nations as competitors in a sense is reminiscent of the falling off of the U.S. dominant position in the world economy in the 1960s. Escaping from the war destruction with the exception of Japan's assault on Pearl Harbor while all other powers suffered from it, the United States positioned itself as the only nation to produce war goods, which not only ended its long struggle for coming out of the economic depression but also made it possible for the United States to achieve rare economic growth during the wartime. So, when the war came to an end, the United States found itself almost invincible economically in the early post-war era. ${ }^{\text {iii }}$ Expectedly, however, by the early 1960s, as the others recovered from the ashes caused by the war, the United States began to face economic competition, most notably from Japan and West Germany, rather quickly ending the U.S. dominance. Although circumstantially somewhat different, this similar experience that the United States and Japan went through perhaps explains best the downward movement of the Japanese economy in the post-Cold War era as Japan began to face economic competition from fellow Asian nations.

\section{China Replaced Japan Economically as No. 2}

The weakening Japanese economy and the rise of Asian neighbors, particularly China, as economic competitors against Japan in the post-Cold War era inevitably altered the U.S.-Japan relationship in the economy, which was once considered to be the most important bilateral relationship in the world. Instead of seeing each other as most vital for their economies, both nations now consider China as the most valuable partner. ${ }^{\text {iv }}$

Today, the United States has a far greater investment in China than in Japan, and there has also been the phenomenal rise of the United States' public interest in China. ${ }^{\mathrm{V}}$ To a great extent, thanks to the effective propaganda by the Chinese government in the United States - as can be seen in the government-sponsored Confucius Instituteto promote a positive image of China through the channel of culture for enhancement of American public interests in China politically and economically-China has superseded Japan as the most popular nation from the Orient among American youth, especially college students. ${ }^{\text {vi }}$ In the same token, it is no longer the United States but China in which Japan also makes the most investments. Like the United States, such investment of Japan goes beyond a material sense. 
The government of Japan promotes Japan's investments regarding human resources, encouraging Japanese youth to study in China rather than in the United States for the sake of establishing a strong tie between China and Japan not only economically but culturally and politically as well.

So, hereChina with its rising status as an economic powerhouse is playing a crucial role to alter the U.S.-Japan relationship in the post-Cold War era. Such role of China over the U.S.-Japan relation is not anything new. That is something one can note throughout the history of modern time. It is not an overstatement to say that the U.S.-Japan relationship has indeed been evolving to a great extent over their interests in China.

Beginning with the U.S. opening of Japan in the mid-19th century, there was, as one of the key motives, the United States' interest in establishing commercial ties with China. That led to the United States' desire to end Japan's seclusion to use Japan as a stationary place to reach China. After the opening of Japan, its successful modernization, and the rise of Japan as one of the imperial and colonial powers, the United States and Japan now as equal powers began to confront each other over their interests in establishing their hegemony in the Pacific in the late $19^{\text {th }}$ century and the early $20^{\text {th }}$ century. China became a focal point in that confrontation as reflected in their political and economic disputes over Japan's victories in the Sino-Japanese War, 1894-1895 and the following Russo-Japanese War, 19041905. Then the United States and Japan further intensified their confrontation against each other when Japan made political and territorial aggressions into China in the early $20^{\text {th }}$ century as exemplified in Japan's Twenty-one Demands against China in 1915, the Manchurian Incident in 1931 violating Japan's own pledge to respect and defend China's independence, sovereignty, and territorial integrity under the Nine-Power Treaty, and the China Incident in 1937, which led to the Second Sino-Japanese War, greatly undermining the United States' economic and political interests in China. Along with the other contending issues, the Japanese aggressions in China eventually led to the Pacific War between the two nations when both nations saw nothing but war as the only means to end the contention. Then, when the war came to an end, there was a sharp reversal in their positions over China. While the United States provided vigorous efforts to protect China from Japanese aggression prior and during the war, China became one of the arch adversaries toward the U.S. when the CCP took power in 1949, turning China into a communist nation. Japan desired to treat China, once an enemy, particularly during the war, not as an adversary but a trade partner, taking China as an indispensable nation if there ought to be any success of Japan's economic recovery in the post-war era. It became an issue of diplomatic confrontation between the United States and Japan as the U.S. persistently opposed such rapprochement of Japan toward China. Then, in the early 1970s, the United States-facing a crucial problem in its internal politics under Nixon and an external one over Vietnam - rather abruptly flipped its position toward China from seeing China as a foe to treating it as a friend. Although it did not constitute a serious loss to Japan economically or even politically, it was enough for Japan to raise some doubt and concern regarding the image of the United States as Japan's most trustworthy ally. Moreover,

Today the United States and Japan are once again at a turning point in their relationshipto China and its rise as an economic powerhouse. This time, however, there is one crucial difference regarding China in the U.S.-Japan relationship. In the evolvement of their relation over China, before the end of the Cold War, China had never been in a position to play an influential role as a powerhouse while Japan had been a sole power in Asia. China played the role of victim exploited by the United States and Japan who were confronting each other only to seek their political and economic interests in China. Now with its rise as one of the major powers in Asia, China has positioned itself to be once again a focal point in the U.S.-Japan relationship but not as a minor or a victim; rather, this time as an equal or even superior power. Thus, for the very first time in Asia, two dominant powers-China and Japan-co-exist as equals, creating a likely confrontation between them to determine which one will be a hegemonic power in Asia in the $21^{\text {st }}$ century. It is beyond anyone's comprehension about what impacts this unprecedented development brings to the U.S.-Japan relationship. One such impact, as afro-mentioned, is already apparent. The United States and Japan both see China as the most vital partner for their economies, bringing the U.S.-Japan relation into an uncharted dimension not only economically but also politically. In a sense, China is no longer a pawn in a "chess match" between two key players: the United States and Japan but wants to replace one of them, or perhaps China wants to bring an end to the chess match and to establish its status as a sole world power.

\section{Normalcy in Politics and End of the Yoshida Doctrine?}

In addition to this drastic turnaround of the Japanese economy in the U.S.-Japan relationship during the post-Cold War era, needless to say, changes in Japanese politics were also inevitable. One of the most crucial issues over the expected changes has to do with the Yoshida Doctrine. As the offspring of the Cold War, the Yoshida Doctrine has been one of the foundations to determine the nature of Japanese politics, particularly regarding Japan's national security issue with the United States. 
Although it has survived and remains unchanged even today, the Yoshida Doctrine has been the source of almost perpetual controversy throughout the Cold War era and continued to be so during the post-war era. Interestingly it could have been over a long time ago when the Korean War took place in 1950 and the U.S. demanded the rearmament of Japan by revising the post-war Japan Constitution. Japan, however, skillfully evaded such demand under the leadership of Yoshida.

Believing that Japan ought to be neutral in its post-war international position, the socialist parties firmly opposed the Yoshida Doctrine, especially with regard to the security arrangement with the United States as it was made when the U.S. occupation came to an end in 1952, and the Peace Treaty and the Security Treaty were concluded. Not only the socialists but the liberal-minded right-wing politicians, most notably Prime Minister Hatoyama Ichiro, demanded the end of the Yoshida Doctrine to establish the true sense of sovereignty of Japan and equality in its relationship with the United States. They sought constitutional reforms for the removal of Article IX from the Constitution and therearmament of Japan.

Despite such persistent oppositions and controversy of the treaty revision in 1960, thanks to the rise ofa strong proAmericanPrime Minister KishiNobuske,the Yoshida Doctrine survived. By the time the 1970s began, there was the rise of Japan's new image as a peace-abiding nation and its role to promote world peace, indicating in a sense an acceptance of the Yoshida Doctrine by the Japanese public, including Japanese youth who were once radically opposed to Japan's security arrangement with the United States in the 1960s.

With such acceptance, Japan now had established its new role internationally to be a symbol of peace, supported by its public and increasingly by the world community as well. As it turned out, however, while Japan was going through such image change, the opposition to the Doctrine never ceased to exist. There was a rising new wave of opposition to the Doctrine in the 1970s and 1980s led by the ultra-right wing Japanese leaders, especially the influential intellectuals, such as Mishima Yukio or Ishihara Shintaro. Like Hatoyama, they took a position of revising the Constitution to end the Japanese reliance on the U.S. defense shield to protect the nation and to establish a true sense of national sovereignty. Mishima was known as a fanatic right wing and one of the most well-known Japanese authors in the postWWII era. He killed himself on November 25, 1970, by carrying out a traditional suicide ritual (hara-kiri) when he failed to cause a coup to bring back pre-war monarchism. ${ }^{\text {vii }}$ Such fanaticism of Mishima was ridiculed by the Japanese public, particularly Japanese youth, who became content with the U.S.-Japan security arrangement by the 1970s, coming to the realization that Japan's high growth in the economy and subsequent affluence and stability were greatly attributed to such arrangement (the Yoshida Doctrine). ${ }^{\text {viii }}$

Ishihara Shintaro, a close friend of Mishima, was outraged by such denigration of Mishima by the Japanese public. Like Mishima, Ishihara, also a right-wing nationalist, a prominent author, and an influential and provocative political figure, became a driving force to end the Yoshida Doctrine. As he called Yoshida a "fool," Ishihara became one of the vehement critics toward the Yoshida Doctrine, believing that it led Japanese politics astray. He shared Mishima's stance and apprehension over the national direction of Japan under the Yoshida Doctrine. Ishihara, while fundamentally accepting the necessity and merits of the U.S.-Japan relationship, became a vehement advocate for the establishment of the equal footing of Japanese politics in dealing with the United States by ending the Yoshida Doctrine. Such desire of Ishihara culminated in his highly controversial book, The Japan That Can Say No. It was written in 1989 in the midst of the Japanese economic heyday. In his writing, Ishihara contended that Japan, now as a highly advanced and competitive nation, especially in technology and trade, even out-competing the United States, had to discard the longlasting servility and submissiveness in its relations with the U.S. and to establish a true sense of partnership based on "equality" by standing on its own feet and indeed by being able to say "No" to the United States. ${ }^{\text {ix }}$ Well, despite this strong and persistent anti-sentiment toward the Yoshida Doctrine and the desire of its termination from both the left and right-wing nationalists, the Doctrine has survived. Now the Cold War came to an end. It was the triumph of democracy. Although it does not mean, of course, there are absolutely no elements of the adversary at all against democracy; it took away, however, the primary reason for Japan to be a buffer zone. Today, nothing about Japan as one of the most advanced nations in the world reminds Japanese people of the national survival days that Japan had to endure during the early post-WWII period. So, as Ishihara emphasized, there is no reason for Japan to continue to face the dishonorable labeling of Japan as being an American dependent. In short, there is no longer a justification for the Yoshida Doctrine to continue.

\section{The Gulf Crisis and Its Impact on U.S.-Japan Relations}

During the post-Cold War era, such emphasis by Ishihara is shared not only by Japanese nationals but increasingly by the foreign nationals. Such voices became particularly louder when the Gulf War took place in 1991 and Japan handled its involvement in thewar poorly. The Gulf War broke out when the dictator of Iraq, Saddam Hussein, took over Kuwait, a nation rich in oil, in $1991 .^{\mathrm{x}}$ 
This takeover of Kuwait by Saddam almost instantly caused panic to the Western powers, including Japan, which were heavily relying on Middle Eastern oil to sustain their economies. United States President George H. Bush mobilized the U.S. troops to liberate Kuwait from Saddam's control. Most of the other Western nations agreed with the United States' decision to use its military to deal with the crisis by sending their troops. Japan, on the other hand, due to its constitutional limitation, fell short of sending its troops but made substantial contributions financially. Japan spent in total $\$ 13$ billion, which was the largest monetary contribution to cover the war cost.

Japan, however, faced sharp condemnation from the Western powers and their peoples, especially from the United States. Regardless of how much money Japan was spending, the Western powers could not accept the fact that Japan as a nation - heavily relying on Middle Eastern oil more than any other nation - was not sending its troops at all while their troops were making ultimate sacrifices to protect oil from the Middle East that was not only vital for their economies but also indeed a "lifeline" for the Japanese economy.

So, as seen multiple times throughout the post-WWII era, the Gulf War stirred up the familiar debate and antisentiment over the Yoshida Doctrine once again. In the early 1950s, there was the vehement United States' effort led by U.S. Secretary of State, Foster Dulles, to bring Japan into the "collective" security arrangement in the Pacific, which required Japan's military involvement such as dispatching SDF (Self Defense Force) as part of the United Nations' peacekeeping forces for the defense of democracy and free economy from the communist threat.As he rejected the U.S. demand for re-arming Japan by revising the post-war Japan Constitution when the Korean War broke out, Yoshida had no desire to lead Japan to such arrangement, believingthat it would undermine his hard established mechanism, the Yoshida Doctrine, to bring about Japan's full recovery in the economy and politics as promptly as possible. Now, in the early 1990s, Japan found itself in a similar setting due to the crisis caused by Saddam's unlawful act. Like four decades ago, this crisis created the stage in which Japan was urged to take part in the "coalition" effort led by the United States and the United Nations by taking a forthcoming and decisive role and policy such as sending its SDF. Here, Japan once again decided to hold to the constitutional limitation as an excuse for not committing its troops despite the drastic change of circumstance in the post-Cold War era and the strong demand from the international community; understandably creating vehement condemnation against Japan for its falling short of taking an appropriate role as one of the leading powers once again.

It is interesting to note, however, that when Saddam Hussein caused another crisis, Japan responded in a sharply contrasting manner. The U.S. War in Iraqbroke out in 2003 when the United States invaded Iraq due to Iraq's repeated failures to comply with the United Nations' resolution for the elimination of Iraq's production and use of weapons of mass destruction (WMD) ${ }^{\mathrm{x}}{ }^{\mathrm{i}}$ While, with the exception of the British, most of the U.S. allies - unlike in the case of the Gulf War-opposed this U.S. invasion of Iraq, Japan was prompt to indicate its support for the U.S. action. Acceding to the U.S. position on Iraq and the use of its military, Prime Minister of Japan, Koizumi Junichiro, spoke at the United Nations General Assembly and strongly denounced Iraq as a threat to the world community. He urged Iraq to comply with the UN Security Council Resolutions. ${ }^{\text {xii }}$ In the aftermath of the war, when the United States made a request to Japan to dispatch its SDF to Iraq to restore order, Koizumi did not hesitate to do so. On June 26, 2003, the government of Japan passed the Iraq Humanitarian Reconstruction Support Special Measure, enabling Japan to dispatch the SDF for humanitarian efforts and reconstruction of Iraq, thus making it possible for Japan to have its troops on foreign soil for the very first time since the end of the Pacific War despite the still existing constitutional limitation. ${ }^{\text {xiii }}$

Why was there such a contrast in Japan's responses to these two crises: the Gulf War in 1991 and the U.S. War in Iraq in 2003? While multiple factors can be raised here, most compelling is the sharp decline of Japan's position in the world community. In 1991, although, as it turned out, Japan was about to face a sudden turnaround of its economy, Japan was still at the pinnacle of economic success, boosting its status as the second largest economy and most competitive nation in technology and trade. In 2003, however, Japan found itself in an awfully different position. Japan was already suffering from more than a decade-long economic stagnation and steep competition from the other rapidly rising Asian nations, particularly China, which was seemingly on the horizon to take over Japan as the most powerful nation in Asia economically. Such economic decline of Japan and the simultaneous rise of China as a world economic power obliged Japan to find itself in the increasingly difficult situation not only economically but politically as well as shown in the United States' inclination toward China rather than Japan for its economic interests, clearly undermining Japan's longlasting hegemonic power in Asia. The United States and the other Western powers began to view not Japan but China as a supreme power in Asia.

In addition to these sobering changes and realities that Japan faced in the Asian Pacific, there was one other harsh reality Japan had to confront. That is a military threat from its neighbors: North Korea and increasingly China as well as it expanded its military might utilizing its newly established economic success. Due to the proximity of North Korea to Japan and the status of North Korea as a nuclear power led by the dictator, Kim Jong-il, a military threat from North Korea was something Japan could not take lightly at all. ${ }^{\text {xiv }}$ 
Thus, massive and rapid military build-up of China became a serious issue for Japan's national security. While there was not much chance of an outright military confrontation between Japan and China due to the strong need of each other for their economies, Japan was becoming increasingly apprehensive about its territorial disputes with China, particularly over the islands known as Senkaku in Japan and Daoyu in China, China's territorial claim in the South China Sea, and the unsettled issues regarding Japan's war crimes against China and its people, undermining Japan's economic interest in the region and so building up a possible military clash with China.

In addition to all these, there are two other factors to look into as explanations for Japan's sharply different response to the U.S. War in Iraq in 2003 from that of the Gulf War in 1991. One is the impact of the 9/11 incident in 2001. This unprecedented attack by the Islamic terrorists on the mainland of the United States killed nearly 3,000 individuals, which included victims of 11 other nations, including Japan. ${ }^{\mathrm{xv}}$ Japan's response to the incident was swift under the leadership Prime Minister Koizumi. Koizumi personally called U.S. President George W. Bush to offer Japan's aid. Koizumi even proposed the dispatch of its SDF overseas as part of Japan's aid for the American fight again terrorism. Japan's quick response to the U.S. crisis is partially explained by Prime Minister Koizumi being strong pro-U.S. and a firm believer of the indispensability of the U.S.-Japan relationship not only to Japan's national security but also for maintaining peace and political and economic stability in the Pacific. The most compelling reason, however, might be Koizumi's desire to respond to the sharp condemnation from the Western community against Japan by making up for its failure to meet an expectation in response to the Gulf War crisis in 1991. As one other factor, there was trend of globalization in the world economy and politics during the post-Cold War era. The impact of such trend is particularly prominent in the U.S.-Japan relationship. Throughout the post-WWII era roughly until the end of the Cold War, the United States and Japan were two dominant powers in the Pacific. It was pretty much monopolization of the economy and politics by them. As looked into earlier, that was drastically altered with the rise of other Asian nations economically such as the Four Tigers and China, followed by India in the post-Cold War era, ending Japan's status as an only industrialized nation in Asia. This globalization trend is now seen not only in the Asian Pacific but also Latin America as exemplified by the rise of Brazil as an economic powerhouse, making the dominance of the world economy and politics by three principal powers: Europe, Japan, and the United States during the 1980s only a matter of "nostalgia."This rise of multiple economic powerhouses throughout the world and the subsequent rise of increasingly globalized enterprises such as Microsoft in the computer industry or Toyota in the automobile industry, buttressed by the breathtaking advancement of high tech, makes the world economy function no longer bilaterally but increasingly multilaterally, and thus diminishing the value of bilateral ties between any two nations as typically seen in the U.S.Japan relations. Before this rapid globalization, there was a saying, "When the United States catches a cold, Japan sneezes, verse versa."

So, due to these significant changes in economic and political circumstances taking place in a rather short time span, only a little over decade later, Japan found itself in profoundly different and troubled waters in 2003, urging Japan to seriously re-assess its relations with the United States, particularly with regard to its national security issue, thus resulting into quite an altered Japanese response to the crisis in 2003.

\section{Changing Relations}

Now, does this changing circumstance as described above mean a devaluation of the United States-Japan relationship, rendering it mediocre or even trivial? The answer to the question is obviously "No." On the contrary to the rising expectation of diminishing values in the U.S.-Japan relationship and in spite of the drastically altered U.S.-Japan economic relations due to the end of the Cold War and the surging power of the Chinese economy, there are still circumstantial elements that demand a fundamentally solid U.S.-Japan relationship. For example, with the fall of Japan economically and the simultaneous rise of China, is the United States expecting China to replace Japan as a reliable partner in maintaining peace and stability in the Asian Pacific? If so, how folly it sounds! Realistically, how can it be possible for anyone to ask: Can China replace Japan to take on the role that Japan has been playing to defend democracy and capitalism along with the U.S. when China, although portraying itself as a nation of capitalism, still pretty much remains to be a communist nation politically and a chance for China to transform itself as a democratic nation is almost next to none? Moreover, one has to see, unlike Japan being known as a nation of homogeneity, China is a diversified nation ethnically. There are around sixty major ethnicities in China today. Considering the historical background of how China established such diversity, it is quite likely that, once China becomes democratic, China would be disintegrated. ${ }^{\text {xvi }}$ If there is anything that holds China as one nation, it is nothing but the "iron fist" of Communism. Today's leaders of China are painfully aware of it.

Sharing the core principles of democracy and capitalism, despite their sharp differences in culture and the confrontations they faced against each other from time to time, the United States and Japan have established one of the most stable and long-lasting relationship. It has been more than 70 years since the end of World War II and continues. 
So, it is almost unthinkable and unrealistic to expect China to take a similar role to that of Japan when China and the United States are standing at diametrically different ends from each other ideologically —one as a nation of democracy and the other still a nation of totalitarianism, having absolutely little room for co-existence. The rise of China economically brought the United States closer to China, which is primarily based on the U.S. economic interest, not a political one. To think that such closeness of the United States and China economically somehow brings a political one as well is only an idiocy.

One should note also that sustainability of the United States' economic interest in China is increasingly becoming questionable today due to the mounting problems China has faced in recent years. When China took over Japan as the second largest economy in the world around the year 2010, China was more like a runaway train, unstoppable in its economic advance with an annual economic growth rate of 9 to 10 percent of the gross domestic product (GDP). Today, only after a half decade or so, China is like the $19^{\text {th }}$ century type of an old locomotive on the rusty railroad with a yearly growth rate of only 2 to 3 percent (the CCP claimed 6 to 7 percent). According to some economic experts, the growth rate of China's economy today is negative. Even the high growth rate that China boasted in the late 1990s and the first decade the of $21^{\text {st }}$ century, some Western economists point out, was overly inflated, having little substance as it was supported by the "bubble economy" and deceptive nature of the Chinese communist leaders. Moreover, as a clear sign of China's economic decline, China has recently slipped from its position as the world's biggest creditor nation as Japan regained it back. One of the most authoritative figures in Chinese studies, Gordon Chang, makes a bold yet quite likely prediction by asserting an imminent collapse of the Chinese economy.

In addition to a deteriorating Chinese economy and the consequential decline of economic ties between the United States and China, there is rising political tension between the two nations as China faces territorial disputes with Japan over the islands known as Senkaku and Daoyu (in this dispute, the U.S. firmly supports Japan), and also makes aggressive territorial claims in the South Indo China Sea, creating a strong protest against China from some of the Southeast Asian nations and more significantly the apprehension in the minds of the U.S. leaders regarding China as a rising threat to U.S. interests and stability in the southern Pacific.

This growing economic crisis of China, the subsequent and alarming social instability in China, and the political tension between China and the Western powers raise a "red flag" over the prospect of China becoming a reliable partner for the United States. Instead, there is a growing expectation today that China, after all, would be no different from the Soviet Union, following the same path the Soviet Union took, self-destruction. Throughout the 1990s and at the turn of the century, few nations had such expectation despite the unanticipated debacle of China's Tiananmen Square Incident in 1989. ${ }^{\text {xvii }}$ Today, Chinaresembles the Soviet Union as it was in 1991, suggesting a possible disintegration of China.

So, in the end, it is possible to argue that the U.S.-Japan relationship, although inevitably with substantial altercations in its nature due to different circumstances in politics and economy in the $21^{\text {st }}$ century, would continue to be vital as it has been for the political and economic stability of the Pacific. In the past, the United States and Japan have gone through several crises that might have either fundamentally altered their relations or ended it entirely. Nevertheless, the two nations have survived. Although still premature to say definitely, the current crisis in their relationship caused by the drastic changes in circumstances as a result of the end of the Cold War and the rapid and strong rise of China as a nation of hegemony in Asia might turn out, in the end, to be no different to the previous ones.

\section{Notes}

${ }^{\mathrm{i}}$ United States Congressional Subcommittee on East Asian and Pacific Affairs. Hearing on U.S.-Japan Relations. $111^{\text {th }}$ Congress, $2^{\text {nd }}$ session, April 15, 2010, pp. 7-8.

ii This explains the impressive economic upturn of the U.S. under President Clinton's administration in the 1990s. As indicated by the sudden rise of the U.S. stock market and simultaneously taking place a sharp decline of the Japanese market, there was worldwide expectation of the rise of the U.S. and the downfall of Japan.

iii This seemingly unquestionable economic invincibility of the U.S. brought an illusion to the minds of the American people. That is "American Exceptionalism." American people began to think that America was blessed by God economically and so America would never cease to be affluent. They indeed thought America was exceptional. This illusion turned out to be awfully costly as seen in Lyndon Johnson's debacle in his belief that he would be victorious in his war on poverty and the Vietnam War simultaneously with such endless affluence of the United States. Losing two wars not only cost him his reelection but far more significantly brought grave social decadence of the United States.

${ }^{\text {iv }}$ As Mr. Alexander A. Arvisu, Deputy Assistant Secretary of the Bureau of East Asian and Pacific Affairs, stated at the Congressional Hearing, "there is a warning voice to this rising power of China and the inclination of both the United States and Japan now to see China more vital to each other. That is, the rise of China and the rise of strong interest in things about China might cause a serious risk of committing a grave mistake to overlooking significance of Japan in her relation with 
the United States." See "U.S.-Japan Relations: An Overview" Hearing, Committee on Foreign Affairs House of Representatives, June 12, 2008, p. 26.

vU.S.-Japan Relations, Congressional Hearing, April 15, 2010, p. 13.

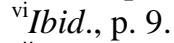

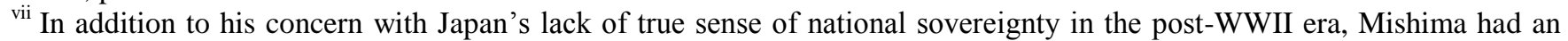
even deeperapprehension. That is the destruction or disappearance of the essence of being Japan or Japanese, particularly with regard to the change in the role of Emperor from monarch to just being a symbol of the nation. As the young military officers in 1930s did, Mishima firmly believed that Japan had to re-establish Constitutional monarchism by restoring sovereignty of the Emperor in order to prevent Japan from "ceasing" to be Japan. It was this apprehension that led Mishima to his suicide. On November 25, 1970, Mishima and his three followers, all dressed as military officers, took over the military building in Tokyo. Shortly before his suicide, Mishima made a speech to the military officers. It was broadcast live on television.

viii The Japanese youth in the 1970s are such a contrast compared to the youth in the 1960s who were vehemently opposed to the government's position with regard to Japan's security arrangement with the U.S. as seen in the student movement against the revision of the U.S.-Japan Security Treaty in 1960. As Japan established affluence of its society and status as one of the economic powerhouses in the world community by the 1970s, such radicalism seen in the students against the government and the anti-sentiment against the U.S. began to fade. It was replaced by their acceptance and understanding of the merits of the U.S.-Japan security arrangement and the two nations' overall relationship.

${ }^{\mathrm{ix}}$ ShintaroIshihara The Japan That Can Say No: Why Japan Will Be First Among Equals (New York, NY: Simon\& Schuster, 1989), pp. 141-48.

${ }^{\mathrm{x}}$ Saddam made his decision to take over Kuwait mainly to end Kuwait's over-production of oil, which, he believed, was undermining his effort to establish the reconstruction of Iraq from the war against Iran, and he also thought it was tantamount to the act of war against Iraq. See Amy L. Catalinac, "Identity Theory and Foreign Policy: Explaining Japan's Responses to the 1991 Gulf War and the 2003 U.S. War in Iraq" in the Journal ofPolitics and Policy, vol. 35, no. 1 (2007), pp. 58-100.

${ }^{x i}$ Ibid., p. 64.

xii Ibid., p. 65.

xiii Ibid.

${ }^{\text {xiv }}$ This threat from North Korea is increasingly intensified today for Japan due to the provocative act of launching missiles over the islands of Japan by Kim Jong-un (known as a mad man), who took power after his father's death in December 2011. The Western powers including the U.S. have been issuing a series of warnings against Kim Jong-un. There has been no response from Kim Jong-un but defiance.

${ }^{\mathrm{xv}}$ Kent E. Calder, Pacific Alliance: Reviving U.S.-Japan Relations (New Haven, CT: Yale University Press, 2008), p. 136.

${ }^{x v i}$ Unlike the U.S., which in a sense started out from the beginning as a melting pot nation, having diversity as its source of national strength, China began its history as a homogenous nation dominated by an ethnic group called Han. Due the constant intrusions by foreign ethnic groups throughout the history of China up until the Qing Dynasty, China, however, stands today as one of the most diversified nations in the world. China has around 60 major ethnic groups including Tibetans, Mongolians, and Manchus. Diversity in China, understandably, became a source of conflicts economically and politically as well exemplified by the long-lasting the Sino-Tibetan conflict and also one of the major weaknesses of China as a nation; that is, the lack of a strong sense of national identity due to such diversity. So, while diversity in the United States is blessing, it is fomentation in China.

${ }^{x v i i}$ On June 4, 1989, students and intellectuals of China gathered at Tiananmen Square for a massive demonstration to demand the government's action for democratization of China. Afraid that the demonstration would uncontrollable, the government of China tried to suppress it by mobilizing the PLA. It was broadcast worldwide on television, changing the image of China almost overnight. Before this incident, the world held a positive image of China as it was seemingly on the way to truly becoming a democratic nation through rapid changes economically to be a nation of capitalism and democracy. The incident shattered China's image. China turned from a peaceful law-abiding nation to the most oppressed nation on earth. 